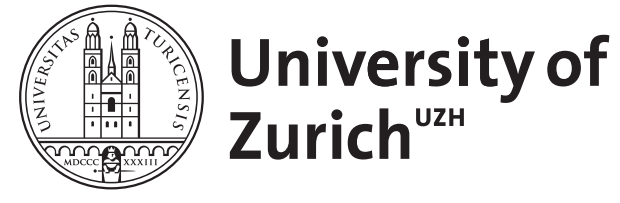

\title{
Widespread anthelmintic resistance in European farmed ruminants: a systematic review
}

Rose, H ; Rinaldi, L ; Bosco, A ; Mavrot, F ; de Waal, T ; Skuce, P ; Charlier, J ; Torgerson, P R ; Hertzberg, H ; Hendrickx, G ; Vercruysse, J ; Morgan, E R

DOI: https://doi.org/10.1136/vr.102982

Posted at the Zurich Open Repository and Archive, University of Zurich ZORA URL: https://doi.org/10.5167/uzh-110037

Journal Article

Accepted Version

Originally published at:

Rose, H; Rinaldi, L; Bosco, A; Mavrot, F; de Waal, T; Skuce, P; Charlier, J; Torgerson, P R; Hertzberg, H; Hendrickx, G; Vercruysse, J; Morgan, E R (2015). Widespread anthelmintic resistance in European farmed ruminants: a systematic review. Veterinary Record, 176(21):546.

DOI: https://doi.org/10.1136/vr.102982 
Rose, $H .^{a, b}$ (BSc, PhD), Rinaldi, L. ${ }^{c}$ (BSc, PhD, AssEVPC), Bosco, A. ${ }^{c}$ (DVM, PhD), Mavrot, F. ${ }^{d}$ (DVM), de Waal, T. ${ }^{e}$ (BVSc, PhD, DipDatMet, HDipUTL, DipEVPC), Skuce, P..$^{f}$ (BSc, PhD), Charlier, J.g (DVM, PhD, DipEVPC), Torgerson, P. R. ${ }^{d}$ (BA, VetMB, PhD, DEVPH, MRCVS), Hertzberg, H. ${ }^{h}$ (DVM, DipEVPC), Hendrickx, G.' (DVM, PhD), Vercruysse, J.g (DVM, DipEVPC), Morgan, E. R. ${ }^{\mathrm{b}, j}(\mathrm{MA}$, VetMB, PhD, DipEVPC, MRCVS)

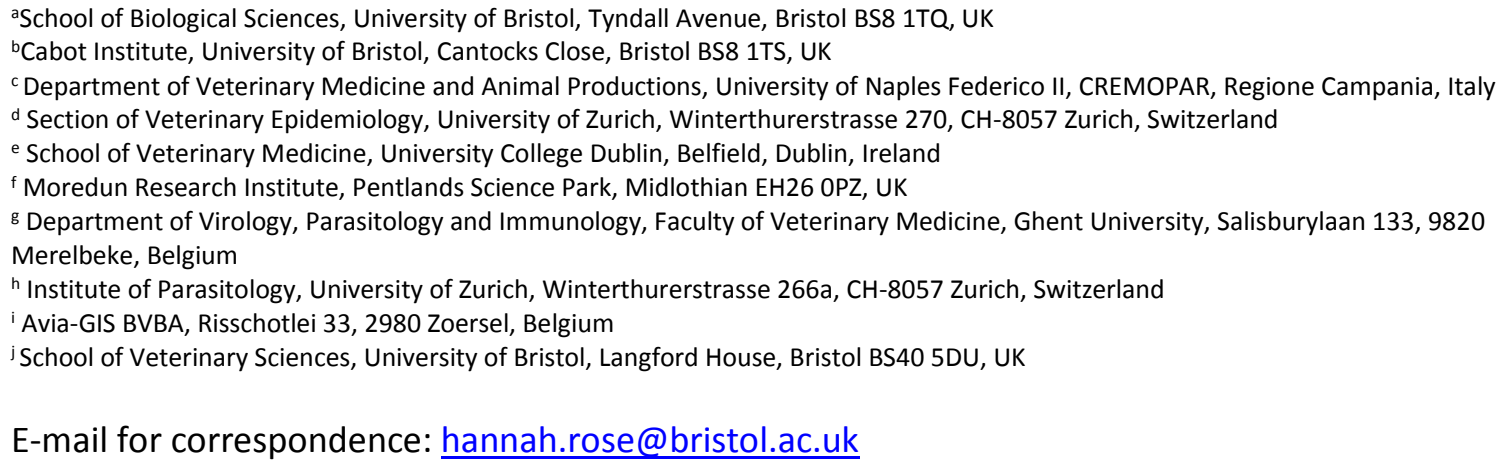

Anthelmintic resistance (AR) in gastrointestinal nematodes (GINs) has been reported worldwide in multiple nematode and livestock species (Kaplan and Vidyashankar 2012) and is a major constraint on production on affected farms (Sutherland and others 2010, Miller and others 2012). In the UK and Ireland for example, AR in GINs and anthelmintic treatment failure is widespread in sheep (e.g. Bartley and others 2003, Keane and others 2014) and increasingly reported in cattle (e.g. O'Shaughnessy and others 2014). There is, therefore, a need to develop and adopt GIN control strategies that maintain the efficacy of anthelmintics and to identify risk factors for the development of AR.

Environmental constraints on farm management and the survival of nematodes in refugia appear to play an important role in the development of AR. In a random survey of sheep farms in Norway, AR was found only in coastal regions (Domke and others 2012a). Papadopoulos and others (2001) observed a higher incidence of AR on isolated Greek islands, suggesting that drought hastens the development of AR. In contrast, Rinaldi and others (2014) observed high anthelmintic efficacy in sheep in southern Italy, despite the Mediterranean climate. This was attributed to the low number of anthelmintic treatments (usually 2 per year) and absence of anthelmintic treatments during periods of drought, when environmental constraints on the free-living stages are highest. Calvete and others (2012) identified an association between AR, distance between farms with AR, management and bioclimatic variables on sheep farms in Aragon, Spain. In particular, the association between AR and climatic conditions was attributed to the application of anthelmintic treatments during the winter months, which increases the selection pressure on the already depleted population of nematodes in refugia. Such spatial analyses provide useful insights into risk factors for AR but their application is likely to be limited outside of the region studied. Pan-European spatial analysis and modelling of the distribution of AR may enable the elucidation of common risk factors for the development of AR in European livestock. AR in the major GINs (Teladorsagia spp., Trichostrongylus spp., Haemonchus contortus, Ostertagia ostertagi and Cooperia oncophora) infecting goats, sheep and cattle in Europe (defined as the 
47 European Union (EU), European Economic Area (EEA) and Switzerland). The ISI Web of Science

48 database was explored using the keywords "anthelmintic resistance" (last searched 02/10/14). No

49 restrictions were placed on publication dates. The search yielded 1,852 publications, of which 120

50 publications were selected based on title and abstract, excluding studies on non-ovine, -bovine or -

51 caprine hosts and nematodes, non-European studies and studies where AR arose through artificial

52 selection. A further nine reports of AR were identified from citations, MSc/PhD theses and authors'

53 unpublished data. Of these publications, 73 provided reports of AR in cattle, sheep or goats assessed

54 in accordance with World Association for the Advancement of Veterinary Parasitology guidelines

55 (Coles and others 1992) and stated the country or region where the farms were located.

56 AR in GINs, assessed primarily using faecal egg count reduction tests (FECRT), is widespread in

57 Europe (supplementary figure). Overall, AR was reported in all five GIN genera and in 16 countries

58 throughout Europe (supplementary figure and table). Multiple drug resistance (MDR) in the three

59 main GIN genera infecting sheep and goats was reported in 10 countries (supplementary table). Not

60 all studies tested multiple anthelmintics and, therefore, MDR is likely to be more widespread.

61 Monepantel resistance was reported on sheep farms in the Netherlands in November 2014 (Anon

62 2014) but was not included in the systematic review as details regarding the methods used to assess

63 resistance were not available at the time of writing. AR against derquantel had not been reported in

64 Europe at the time of writing. However, due to publication and sample selection bias, the absence of

65 reports of AR in some regions may simply be due to a lack of monitoring and AR cannot be

66 considered absent elsewhere. Heterogeneity in the distribution of AR in Europe might also depend

67 on the lack of standardized procedures for surveys and detection of AR on farms and in laboratories.

68 The estimated prevalence of AR varied by region, anthelmintic class and host. Random surveys of 69 sheep farms have detected albendazole resistance on $11 \%$ of farms in Norway ( $n=19$; Domke and 70 others 2012a), ivermectin, benzimidazole and levamisole resistance on $23 \%, 3.7 \%$ and $7.4 \%$ of farms, 71 respectively, in Slovakia ( $n=27$; Čerňanská and others 2006), and benzimidazole and levamisole 72 resistance on $83 \%$ and $50 \%$, respectively, of farms in Western France ( $n=23$; Chartier and others 73 1998). In the latter study, benzimidazole resistance was also detected on $93 \%$ of goat farms ( $n=15)$.

74 A further random survey of dairy goat farms in Southwestern France detected benzimidazole 75 resistance on $83 \%$ of farms, and multiple resistance to benzimidazole and levamisole on $11 \%$ of 76 farms ( $n=18$; Chartier and others 2001). A sample size-weighted mean prevalence of benzimidazole resistance in GINs in sheep and goats of $50.1 \%$ was estimated from the above four studies. Excluding goats, the sample size-weighted mean prevalence of benzamidazole resistance in sheep GINs was $32.1 \%$. Insufficient data were available to estimate mean prevalence for other anthelmintic classes and cattle. The prevalence of AR has also been estimated elsewhere e.g. treatment failure has been identified on 51\% of Irish sheep farms surveyed (Keane and others 2014) and 64\% of Scottish sheep farms surveyed (Bartley and others 2003). These studies provide valuable prevalence estimates but differences in sample (farm) selection methods introduce potential sample selection bias and may affect estimates and comparability between regions. For example, Domke and others (2012a) observed AR on $33 \%$ of randomly selected sheep flocks and $80 \%$ of non-randomly selected sheep flocks in the Rogaland region of Norway. Therefore, it is recommended that future prevalence 87 surveys follow a random or stratified sampling approach where possible to reduce sample selection bias. 
89 The biases described above currently prevent robust spatial meta-analysis of AR in Europe and 90 restrict the spatial analysis that can be undertaken. In addition, since spatial analysis is rarely the 91 purpose of a study into AR and due to data protection responsibilities, cases are usually reported at 92 a country or regional level. Due to the significant within-region heterogeneity in the distribution of 93 AR (e.g. Calvete and others 2012), data with a higher spatial resolution are required.

94 Taken together, the peer-reviewed literature paints a picture of widespread AR in Europe with the 95 potential for high regional prevalence.. Veterinarians should continue to promote sustainable 96 anthelmintic use (e.g. Abbott and others 2012, Charlier and others 2014), even on farms where AR is 97 not suspected. Continued surveillance of AR in Europe, reporting the absence of resistance (Paraud 98 and others 2010, Rinaldi and others 2014) and reporting cases in a way that enables spatial meta99 analysis will aid in the future identification of risk factors and evaluation of sustainable nematode 100 control practices.

101

102 Acknowledgements

103 The work was supported by funding from the FP7 GLOWORM project - Grant agreement N ${ }^{\circ}$ 104 288975CP-TP-KBBE.2011.1.3-04 
107 ANON (2014) Monepantel resistance reported on Dutch sheep farms. Veterinary Record 175, 418

108 ABBOTT, K. A., TAYLOR, M. A. \& STUBBINGS, L. A. (2012) Sustainable worm control strategies for sheep: A technical manual for veterinary surgeons and advisers, $4^{\text {th }}$ Edition.

110 http://www.scops.org.uk/content/SCOPS-Technical-manual-4th-Edition-June-2012.pdf. Accessed 111 July 17,2014

112 AlVAREZ-SÁNCHEZ, M. A., PÉREZ-GARCíA, J., CRUZ-ROJO, M. A. \& ROJO-VÁZQUEZ, F. A. (2006)

113 Anthelmintic resistance in trichostrongylid nematodes of sheep farms in Northwest Spain.

114 Parasitology Research 99, 78-83

115

116

117

118

ARESKOG, M., LUUNGSTRÖM, B. \& HÖGLUND, J. (2013) Limited efficacy of pour-on anthelmintic treatment of cattle under Swedish field conditions. International Journal for Parasitology: Drugs and Drug Resistance 3, 129-34

ARTHO, R., SCHNYDER, M., KOHLER, L., TORGERSON, P. R. \& HERTZBERG, H. (2007) Avermectinresistance in gastrointestinal nematodes of Boer goats and Dorper sheep in Switzerland. Veterinary Parasitology 144, 68-73

BARTLEY, D. J., DONNAN, A. A., JACKSON, E., SARGISON, N., MITCHELL, G. B. B. \& JACKSON, F. (2006) A small scale survey of ivermectin resistance in sheep nematodes using the faecal egg count reduction test on samples collected from Scottish sheep. Veterinary Parasitology 137, 112-118

BARTLEY, D. J., JACKSON, E., JOHNSTON, K., COOP, R. L., MITCHELL, G. B. B., SALES, J. \& JACKSON, F. (2003) A survey of anthelmintic resistant nematode parasites in Scottish sheep flocks. Veterinary Parasitology 117, 61-71

BARTLEY, D. J., JACKSON, F., JACKSON, E. \& SARGISON, N. (2004) Characterisation of two triple resistant field isolates of Teladorsagia from Scottish lowland sheep farms. Veterinary Parasitology 123, 189-199

BARTLEY, D. J., MCARTHUR, C. L., DEVIN, L. M., SUTRA, J. F., MORRISON, A. A., LESPINE, A. \& MATTHEWS, J. B. (2012) Characterisation of macrocyclic lactone resistance in two field-derived isolates of Cooperia oncophora. Veterinary Parasitology 190, 454-460

BJØRN, H., MONRAD, J. \& NANSEN, P. (1991) Anthelmintic resistance in nematode parasites of sheep in Denmark with special emphasis on levamisole resistance in Ostertagia circumcincta. Acta Veterinaria Scandinavica 32, 145-154

BOERSEMA, J. H., BORGSTEEDE, F. H., EYSKER, M., HENDRIKX, W. M., JANSEN, J. \& SMITH-BUYS, C. M. (1987) Prevalence of benzimidazole resistance of nematodes in sheep in The Netherlands. Research in Veterinary Science 43, 18-21

BORGSTEEDE, F. H. (1986) Resistance of Cooperia curticei against fenbendazole. Research in Veterinary Science 41, 423-424 
BORGSTEEDE, F. H. \& DUYN, S. P. (1989) Lack of reversion of a benzimidazole resistant strain of Haemonchus contortus after six years of levamisole usage. Research in Veterinary Science 47, 270272

BORGSTEEDE, F. H. M., DERCKSEN, D. D. \& HUIJBERS, R. (2007) Doramectin and albendazole resistance in sheep in The Netherlands. Veterinary Parasitology 144, 180-183

BORGSTEEDE, F. H. M., GEERTS, S., DE DEKEN, R., KUMAR, V. \& BRANDT, J. (1992) Studies on an Ostertagia ostertagi strain suspected to be resistant to benzimidazoles. Veterinary Parasitology 41 , 85-92

BORGSTEEDE, F. H. M., PEKELDER, J. J. \& DERCKSEN, D. P. (1996) Anthelmintic resistant nematodes in goats in The Netherlands. Veterinary Parasitology 65, 83-87

BORGSTEEDE, F. H. M., PEKELDER, J. J., DERCKSEN, D. P., SOL, J., VELLEMA, P., GAASENBEEK, C. P. \& VAN DER LINDEN, J. N. (1997) A survey of anthelmintic resistance in nematodes of sheep in The Netherlands. The Veterinary Quarterly 19, 167-172

BRITT, D. P. \& OAKLEY, G. A. (1986) Anthelmintic evaluation of a thiabendazole-resistant strain of Ostertagia circumcincta recovered from sheep in England. Veterinary Parasitology, 19, 95-101

BURGESS, C. G. S., BARTLEY, Y., REDMAN, E., SKUCE, P. J., NATH, M., WHITELAW, F., TATE, A., GILLEARD, J. S. \& JACKSON, F. (2012) A survey of the trichostrongylid nematode species present on UK sheep farms and associated anthelmintic control practices. Veterinary Parasitology 189, 299-307

CABARET, J., BAUDET, H. M., DEVOS, J., HUBERT, J., CORTET, J. \& SAUVÉ, C. (1995) Studies on mutlispecific resistance of gastrointestinal nematodes to benzimidazoles on dairy-goat farms. Veterinary Parasitology 60, 331-337

CALVETE, C., CALAVIA, R., FERRER, L. M., RAMOS, J. J., LACASTA, D. \& URIARTE, J. (2012) Management and environmental factors related to benzimidazole resistance in sheep nematodes in Northeast Spain. Veterinary Parasitology 184, 193-203

CAWTHORNE, R. J. \& CHEONG, F. H. (1984) Prevalence of anthelmintic resistant nematodes in sheep in south-east England. Veterinary Record 114, 562-564

CAWTHORNE, R. J. \& WHITEHEAD, J. D. (1983) Isolation of benzimidazole resistant strains of Ostertagia circumcincta from British sheep. Veterinary Record 112, 274-277

ČERŇANSKÁ, D., VÁRADY, M. \& ČORBA, J. (2006) A survey on anthelmintic resistance in nematode parasites of sheep in the Slovak Republic. Veterinary Parasitology 135, 39-45

CHARLIER, J., MORGAN, E. R., RINALDI, L., VAN DIJK, J., DEMELER, J., HÖGLUND, J., HERTZBERG, H., VAN RANST, B., HENDRICKX, G., VERCRUYSSE, J. \& KENYON, F. (2014) Practices to optimise gastrointestinal nematode control on sheep, goat and cattle farms in Europe using targeted (selective) treatments. Veterinary Record 175, 250-255 
CHARTIER, C., PORS, I., HUBERT, J., ROCHETEAU, D., BENOIT, C. \& BERNARD, N. (1998) Prevalence of anthelmintic resistant nematodes in sheep and goats in Western France. Small Ruminant Research 29, 33-41

CHARTIER, C., SOUBIRAC, F., PORS, I., SILVESTRE, A., HUBERT, J., COUQUET, C. \& CABARET, J. (2001) Prevalence of anthelmintic resistance in gastrointestinal nematodes of dairy goats under extensive management conditions in southwestern France. Journal of Helminthology 75, 325-330

COLES, G. C., BAUER, C., BORGSTEEDE, F. H. M., GEERTS, S., KLEI, T. R., TAYLOR, M. A. \& WALLER, P. J. (1992) World Association for the Advancement of Veterinary Parasitology (W.A.A.V.P.) methods for the detection of anthelmintic resistance in nematodes of veterinary importance. Veterinary Parasitology 44, 35-44

COLES, G. C., STAFFORD, K. A. \& MACKAY, P. H. (1998) Ivermectin-resistant Cooperia species from calves on a farm in Somerset. Veterinary Record 142, 255-256

CRINGOLI, G., VENEZIANO, V., RINALDI, L., SAUVÉ, C., RUBINO, R., FEDELE, V. \& CABARET, J. (2007) Resistance of trichostrongyles to benzimidazoles in Italy: a first report in a goat farm with multiple and repeated introductions. Parasitology Research 101, 577-581

DEMELER, J., VAN ZEVEREN, A. M. J., KLEINSCHMIDT, N., VERCRUYSSE, J., HÖGLUND, J., KOOPMANN, R., CABARET, J., CLAEREBOUT, E., ARESKOG, M. \& VON SAMSON-HIMMELSTJERNA, G. (2009) Monitoring the efficacy of ivermectin and albendazole against gastro intestinal nematodes of cattle in Northern Europe. Veterinary Parasitology 160, 109-115

DÍEZ-BAÑOS, P., PEDREIRA, J., SÁNCHEZ-ANDRADE, R., FRANCISCO, I., SUÁREZ, J. L., DÍAZ, P., PANADERO, R., ARIAS, M., PAINCEIRA, A., PAZ-SILVA, A. \& MORRONDO, P. (2008) Field evaluation for anthelmintic-resistant ovine gastrointestinal nematodes by in vitro and in vivo assays. The Journal of Parasitology 94, 925-928

DOMKE, A. V. M., CHARTIER, C., GJERDE, B., HÖGLUND, J., LEINE, N., VATN, S. \& STUEN, S. (2012a) Prevalence of anthelmintic resistance in gastrointestinal nematodes of sheep and goats in Norway. Parasitology Research 111, 185-193

DOMKE, A. V. M., CHARTIER, C., GJERDE, B. \& STUEN, S. (2012b) Benzimidazole resistance of sheep nematodes in Norway confirmed through controlled efficacy test. Acta Veterinaria Scandinavica 54, 48

EL-ABDELLATI, A., CHARLIER, J., GELDHOF, P., LEVECKE, B., DEMELER, J., VON SAMSONHIMMELSTJERNA, G., CLAEREBOUT, E. \& VERCRUYSSE, J. (2010a) The use of a simplified faecal egg count reduction test for assessing anthelmintic efficacy on Belgian and German cattle farms. Veterinary Parasitology 169, 352-357

EL-ABDELLATI, A., GELDHOF, P., CLAEREBOUT, E., VERCRUYSSE, J. \& CHARLIER, J. (2010b) Monitoring macrocyclic lactone resistance in Cooperia oncophora on a Belgian cattle farm during four consecutive years. Veterinary Parasitology 171, 167-171

GALLIDIS, E., ANGELOPOULOU, K. \& PAPADOPOULOS, E. (2012) First identification of benzimidazole resistant Haemonchus contortus in sheep in Greece. Small Ruminant Research 106, 27-29 
GEURDEN, T., HOSTE, H., JACQUIET, P., TRAVERSA, D., SOTIRAKI, S., FRANGIPANE DI REGALBONO, A. and others (2014) Anthelmintic resistance and multidrug resistance in sheep gastro-intestinal nematodes in France, Greece and Italy. Veterinary Parasitology 201, 59-66

GOOD, B., HANRAHAN, J. P., DE WAAL, D. T., PATTEN, T., KINSELLA, A. \& LYNCH, C. O. (2012) Anthelmintic-resistant nematodes in Irish commercial sheep flocks-the state of play. Irish Veterinary Journal 65, 21

GRIMSHAW, W. T., HUNT, K. R., HONG, C. \& COLES, G. C. (1994) Detection of anthelmintic resistant nematodes in sheep in southern England by a faecal egg count reduction test. Veterinary Record $135,372-374$

HERTZBERG, H., ROSSMANN, J., KOHLER, L. \& WILLI, U. (2000) Vorkommen von BenzimidazolResistenzen bei Magen-Darmnematoden des Schafes und der Ziege in der Schweiz. Wiener Tierärztliche Monatsschrift 87, 3-9

HÖGLUND, J., GUSTAFSSON, K., LUUNGSTRÖM, B.-L., ENGSTRÖM, A., DONNAN, A. \& SKUCE, P. (2009) Anthelmintic resistance in Swedish sheep flocks based on a comparison of the results from the faecal egg count reduction test and resistant allele frequencies of the beta-tubulin gene. Veterinary Parasitology 161, 60-68

HONG, C., HUNT, K. R. \& COLES, G. C. (1996) Occurrence of anthelmintic resistant nematodes on sheep farms in England and goat farms in England and Wales. Veterinary Record 139, 83-86

HONG, C., HUNT, K. R., HARRIS, T. J., COLES, G. C., GRIMSHAW, W. T. \& MCMULLIN, P. F. (1992) A survey of benzimidazole resistant nematodes in sheep in three countries of southern England. Veterinary Record 131, 5-7

JACKSON, F., JACKSON, E. \& COOP, R. L. (1992) Evidence of multiple anthelmintic resistance in a strain of Teladorsagia circumcincta (Ostertagia circumcincta) isolated from goats in Scotland. Research in Veterinary Science 53, 371-374

JORDI, R. (1980) Untersuchungen zur Anthelminthika-Resistenz von Trichostrongyliden des Schafes. Schweizer Archiv fur Tierheilkunde 122, 679-694

KAPLAN, R. M. \& VIDYASHANKAR, A. N. (2012) An inconvenient truth: Global worming and anthelmintic resistance. Veterinary Parasitology 186, 70-78

KEANE, O. M., KEEGAN, J. D., GOOD, B., DE WAAL, T., FANNING, J., GOTTSTEIN, M., CASEY, M., HURLEY, C. \& SHEEHAN, M. (2014) High level of treatment failure with commonly used anthelmintics on Irish sheep farms. Irish Veterinary Journal 67, 16

MAINGI, N., BJØRN, H., THAMSBORG, S. M., B ØGH, H. O. \& NANSEN, P. (1996a) A survey of anthelmintic resistance in nematode parasites of goats in Denmark. Veterinary Parasitology 66, 5366

MAINGI, N., BJØRN, H., THAMSBORG, S. M., BØGH, H. O. \& NANSEN, P. (1996b) Anthelmintic resistance in nematode parasites of sheep in Denmark. Small Ruminant Research 23, 171-181 
MARTÍNEZ-VALLADARES, M., DONNAN, A., GELDHOF, P., JACKSON, F., ROJO-VÁZQUEZ, F.-A. \& SKUCE, P. (2012a) Pyrosequencing analysis of the beta-tubulin gene in Spanish Teladorsagia circumcincta field isolates. Veterinary Parasitology 184, 371-376

MARTÍNEZ-VALLADARES, M., FAMULARO, M. R., FERNÁNDEZ-PATO, N., CORDERO-PÉREZ, C., CASTAÑÓN-ORDÓÑEZ, L. \& ROJO-VÁZQUEZ, F. A. (2012b) Characterization of a multidrug resistant Teladorsagia circumcincta isolate from Spain. Parasitology Research 110, 2083-2087

MARTÍNEZ-VALLADARES, M., MARTÍNEZ-PÉREZ, J. M., ROBLES-PÉREZ, D., CORDERO-PÉREZ, C., FAMULARO, M. R., FERNÁNDEZ-PATO, N., CASTAÑÓN-ORDÓÑEZ, L. \& ROJO-VÁZQUEZ, F. A. (2013) The present status of anthelmintic resistance in gastrointestinal nematode infections of sheep in the northwest of Spain by in vivo and in vitro techniques. Veterinary Parasitology 191, 177-181

MCARTHUR, C. L., BARTLEY, D. J., SHAW, D. J. \& MATTHEWS, J. B. (2011) Assessment of ivermectin efficacy against gastrointestinal nematodes in cattle on four Scottish farms. Veterinary Record, 169, 658

MCMAHON, C., BARTLEY, D. J., EDGAR, H. W. J., ELLISON, S. E., BARLEY, J. P., MALONE, F. E., HANNA, RE. E. B., BRENNAN, G. P. \& FAIRWEATHER, I. (2013) Anthelmintic resistance in Northern Ireland (I): prevalence of resistance in ovine gastrointestinal nematodes, as determined through faecal egg count reduction testing. Veterinary Parasitology 195, 122-130

MEYER, A. (2001) Verbreitung von benzimdazol-resistenzen bei den trichostrongyliden von schafen und ziegen in der Schweiz. PhD thesis, University of Zurich

MILLER, C., WAGHORN, T., LEATHWICK, D. M., CANDY, P. M., OLIVER, A-M. B. \& WATSON, T. G. (2012) The production cost of anthelmintic resistance in lambs. Veterinary Parasitology 186, 376-381

MITCHELL, E. S. E., HUNT, K. R., WOOD, R. \& MCLEAN, B. (2010) Anthelmintic resistance on sheep farms in Wales. Veterinary Record 166, 650-652

MURRI, S., KNUBBEN-SCHWEIZER, G., TORGERSON, P. \& HERTZBERG, H. (2014) Frequency of eprinomectin resistance in gastrointestinal nematodes of goats in canton Berne, Switzerland. Veterinary Parasitology 203, 114-119

O'SHAUGHNESSY, J., EARLEY, B., MEE, J. F., DOHERTY, M. L., CROSSON, P., BARRETT, D., PRENDIVILLE, R., MACRELLI, M. \& DE WAAL, T. (2014) Detection of anthelmintic resistance on two Irish beef research farms. Veterinary Record 175, 120

PALCY, C., SILVESTRE, A., SAUVE, C., CORTET, J. \& CABARET, J. (2010) Benzimidazole resistance in Trichostrongylus axei in sheep: long-term monitoring of affected sheep and genotypic evaluation of the parasite. The Veterinary Journal 183, 68-74

PAPADOPOULOS, E., HIMONAS, C. \& COLES, G. C. (2001) Drought and flock isolation may enhance the development of anthelmintic resistance in nematodes. Veterinary Parasitology 97, 253-259

PARAUD, C., KULO, A., PORS, I. \& CHARTIER, C. (2009) Resistance of goat nematodes to multiple anthelmintics on a farm in France. Veterinary Record 164, 563-564 
PARAUD, C., PORS, I., REHBY, L. \& CHARTIER, C. (2010) Absence of ivermectin resistance in a survey on dairy goat nematodes in France. Parasitology Research 106, 1475-1479

PRASLIČKA, J., VÁRADY, M., ČORBA, J. \& VESELÝ, L. (1994) A survey of anthelmintic resistance in Slovakia. Veterinary Parasitology 52, 169-171

REQUEJO-FERNÁNDEZ, J. A., MARTÍNEZ, A., MEANA, A., ROJO-VÁZQUEZ, F. A., OSORO, K. \& ORTEGAMORA, L. M. (1997) Anthelmintic resistance in nematode parasites from goats in Spain. Veterinary Parasitology 73, 83-88

RINALDI, L., MORGAN, E. R., BOSCO, A., COLES, G. C. \& CRINGOLI, G. (2014) The maintenance of anthelmintic efficacy in sheep in a Mediterranean climate. Veterinary Parasitology 203, 139-143

SARGISON, N. D., JACKSON, F., BARTLEY, D. J. \& MOIR, A. C. P. (2005) Failure of moxidectin to control benzimidazole-, levamisole- and ivermectin-resistant Teladorsagia circumcincta in a sheep flock. Veterinary Record 156, 105-109

SARGISON, N. D., JACKSON, F., BARTLEY, D. J., WILSON, D. J., STENHOUSE, L. J. \& PENNY, C. D. (2007) Observations on the emergence of multiple anthelmintic resistance in sheep flocks in the south-east of Scotland. Veterinary Parasitology 145, 65-76

SARGISON, N. D., SCOTT, P. R., WILSON, D. J., MACRAE, A. I. \& PENNY, C. D. (2010) Teladorsagia circumcincta resistance to moxidectin and multiple anthelmintic groups in ewes following use of the persistent drug before lambing. Veterinary Record 167, 523-527

SCHEUERLE, M. C., MAHLING, M. \& PFISTER, K. (2009) Anthelminthic resistance of Haemonchus contortus in small ruminants in Switzerland and Southern Germany. Wiener Klinische Wochenschrift $121,46-49$

SCHNYDER, M., TORGERSON, P. R., SCHÖNMANN, M., KOHLER, L. \& HERTZBERG, H. (2005) Multiple anthelmintic resistance in Haemonchus contortus isolated from South African Boer goats in Switzerland. Veterinary Parasitology 128, 285-290

STAFFORD, K. \& COLES, G. C. (1999) Nematode control practices and anthelmintic resistance in dairy calves in the south west of England. Veterinary Record 144, 659-661

SUTHERLAND, A. A., SHAW, J. \& SHAW, R. J. (2010) The production costs of anthelmintic resistance in sheep managed within a monthly preventive drench program. Veterinary Parasitology 171, 300304

TAYLOR, M. A., LEARMOUNT, J., LUNN, E., MORGAN, C. \& CRAIG, B. H. (2009) Multiple resistance to anthelmintics in sheep nematodes and comparison of methods used for their detection. Small Ruminant Research 86, 67-70

TRAVERSA, D., PAOLETTI, B., OTRANTO, D. \& MILLER, J. (2007) First report of multiple drug resistance in trichostrongyles affecting sheep under field conditions in Italy. Parasitology Research $101,1713-1716$ 
VADLEJCH, J., KOPECKÝ, O., KUDRNÁČOVÁ, M., ČADKOVÁ, Z., JANKOVSKÁ, I. \& LANGROVÁ, I. (2014)

321 The effect of risk factors of sheep flock management practices on the development of anthelmintic

322 resistance in the Czech Republic. Small Ruminant Research 117, 183-190

323 VAN DEN BROM, R., MOLL, L., BORGSTEEDE, F. H. M., VAN DOORN, D. C. K., LIEVAART-PETERSON, K., 324 DERCKSEN, D. P. \& VELLEMA, P. (2013) Multiple anthelmintic resistance of Haemonchus contortus, 325 including a case of moxidectin resistance, in a Dutch sheep flock. Veterinary Record 173, 552

326 VÁRADY, M., ČERŇANSKÁ, D. \& ČORBA, J. (2006) Use of two in vitro methods for the detection of 327 anthelmintic resistant nematode parasites on Slovak sheep farms. Veterinary Parasitology 135, 325$328 \quad 331$

329 VOIGT, K., SCHEUERLE, M. \& HAMEL, D. (2012) Triple anthelmintic resistance in Trichostrongylus spp. 330 in a German sheep flock. Small Ruminant Research 106, 30-32

331 WILSON, D. \& SARGISON, N. (2007) Anthelmintic resistance in Teladorsagia circumcincta in sheep in 332 the UK. Veterinary Record 161, 535-536

333 ZANZANI, S. A., GAZZONIS, A. L., DI CERBO, A., VARADY, M. \& MANFREDI, M. T. (2014)

334 Gastrointestinal nematodes of dairy goats, anthelmintic resistance and practices of parasite control 335 in Northern Italy. BMC Veterinary Research 10, 114 
Supplementary figure. The distribution of reported cases of anthelmintic resistance (AR) in the European Union, European Economic Area and Switzerland, at national level, based on the systematic review. Shaded countries had at least one reported case of AR. Note that regional distribution within countries is not plotted: see supplementary table for details of drug classes and GIN genera/species, and individual references for specific locations and apparent prevalence. No data were available for Iceland (not shown).

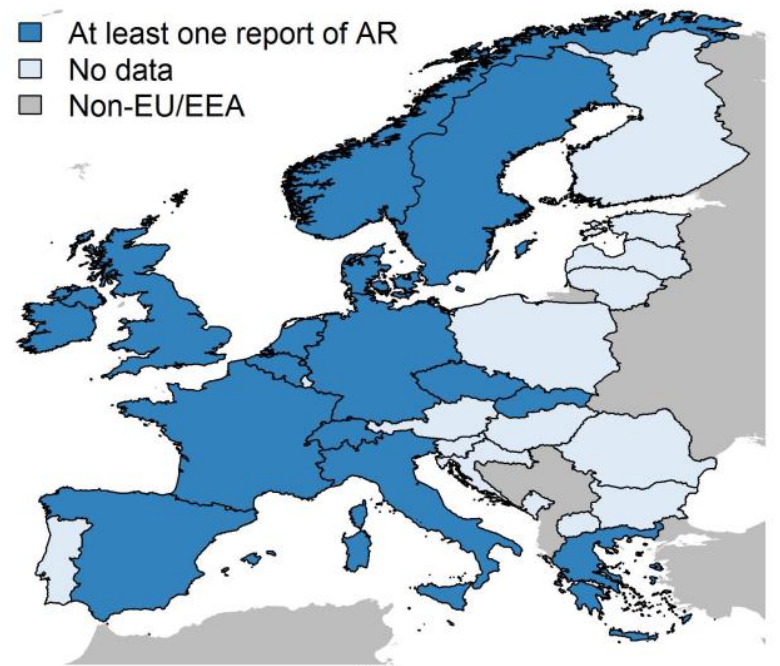

All

343

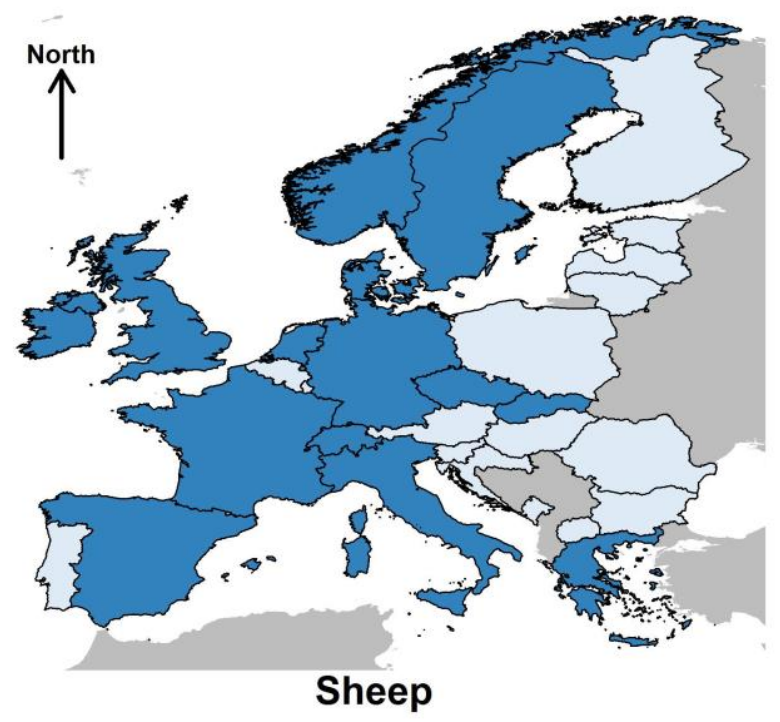

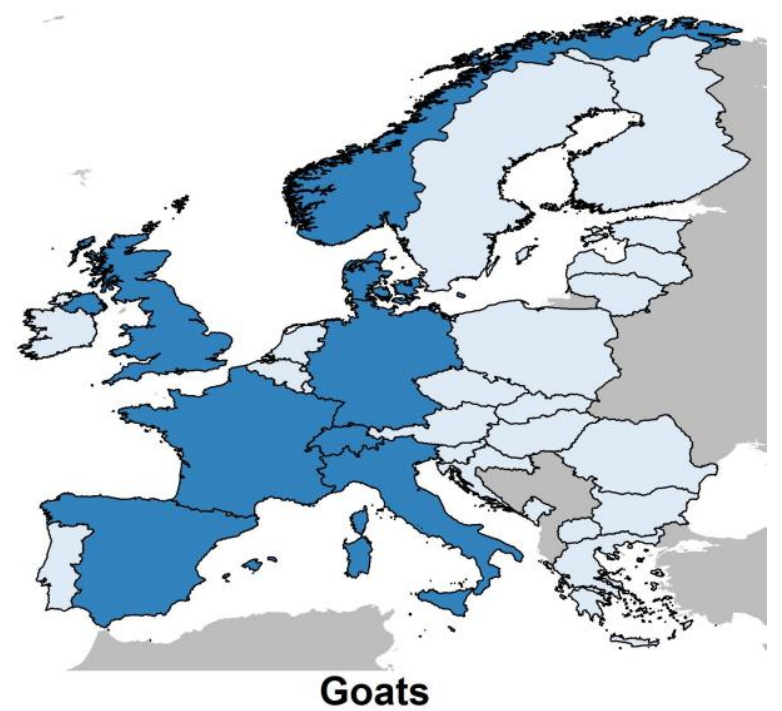

Goats

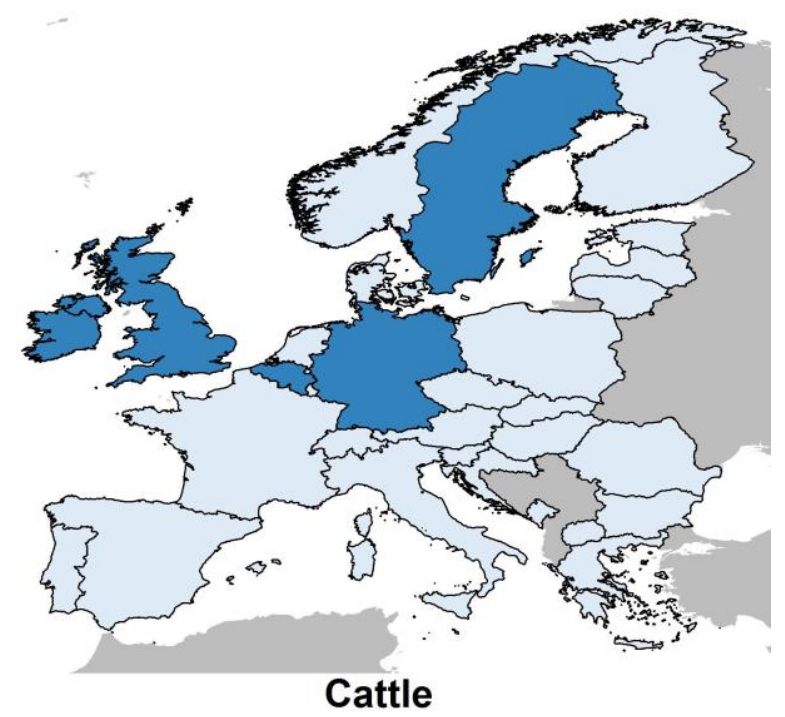

Cattle 

nematode species/genera infecting goats, sheep and cattle in Europe.

\begin{tabular}{lll}
\hline AH Host & Region & References \\
class $^{\text {a }}$ & & \\
\hline
\end{tabular}

Teladorsagia spp.

BZ Sheep Czech

Republic, Denmark, France, Greece, Alvarez-Sánchez and others 2006, Bartley and others 2004, 2006, Bjørn and others 1991, Boersema and others 1987, Borgsteede Ireland, Italy, and others 1997, 2007, Britt \& Oakley 1986, Cawthorne and Whitehead 1983, Cawthorne and Cheong 1984, Čerňanská and others 2006, Chartier and others 1998, Díez-Baños and others Netherlands, 2008, Domke and others 2012a,b, Geurden and others 2014, Norway, Slovakia, Good and others 2012, Grimshaw and others 1994, Hong and Spain, UK others 1992, 1996, Maingi and others 1996b, Martínez-Valladares and others 2012a, McMahon and others 2013, Mitchell and others 2010, Taylor and others 2009, Traversa and others 2007, Vadlejch and others 2014

Goats France, Borgsteede and others 1996, Chartier and others 1998, 2001, Denmark, Italy, Domke and others 2012a, Hong and others 1996, Jackson and Netherlands, others 1992, Maingi and others 1996a, Requejo-Fernández and Norway, Spain, UK

ML Sheep Czech Republic, Denmark, Italy, others 1997, Zanzani and others 2014

Netherlands, Slovakia, Spain, Sweden ${ }^{\mathrm{b}}$, UK

Goats Denmark, Italy, Switzerland, Alvarez-Sánchez and others 2006, Bartley and others 2004, 2006, Borgsteede and others 1997, Čerňanská and others 2006, DíezBaños and others 2008, Höglund and others 2009, Maingi and others 1996b, Martínez-Valladares and others 2012a, b, McMahon and others 2013, Taylor and others 2009, Traversa and others 2007, Vadlejch and others 2014 UK

\section{LEV Sheep Denmark,} France, Alvarez-Sánchez and others 2006, Bartley and others 2004, 2006, Greece, Bjørn and others 1991, Borgsteede and others 1997, Chartier and Ireland, Italy, others 1998, Geurden and others 2014, Good and others 2012, Netherlands, Hong and others 1996, Maingi and others 1996b, MartínezSpain, UK Jackson and others 1992, Maingi and others 1996a, Murri and others 2014, Zanzani and others 2014

Valladares and others 2012b, McMahon and others 2013, Mitchell and others 2010, Taylor and others 2009, Traversa and others 2007

Goats Denmark, France, UK Chartier and others 2001, Hong and others 1996, Maingi and others 1996a 
MDR Sheep Denmark, Greece, Ireland, Italy, Netherlands, Spain, UK
Alvarez-Sánchez and others 2006, Bartley and others 2004, 2006, Borgsteede and others 1997, Geurden and others 2014, Good and others 2012, Maingi and others 1996b, Martínez-Valladares and others 2012b, Mitchell and others 2010, Sargison and others 2005, 2007, 2010, Taylor and others 2009, Traversa and others 2007, Wilson \& Sargison 2007

Goats Denmark, Chartier and others 2001, Jackson and others 1992, Maingi and France, UK others 1996a

Trichostrongylus spp.

BZ Sheep Denmark, Alvarez-Sánchez and others 2006, Bjørn and others 1991, France, Boersema and others 1987, Borgsteede and others 1997, 2007, Greece, Čerňanská and others 2006, Chartier and others 1998, Díez-Baños Ireland, Italy, and others 2008, Domke and others 2012a, Geurden and others Netherlands, 2014, Good and others 2012, Maingi and others 1996b, MartínezNorway, Valladares and others 2013, McMahon and others 2013, Mitchell Slovakia, and others 2010, Palcy and others 2010, Taylor and others 2009, Spain, UK Traversa and others 2007

Goats Denmark, Borgsteede and others 1996, Cabaret and others 1995, Chartier France, Italy, and others 1998, 2001, Cringoli and others 2007, Domke and Netherlands, others 2012a, Maingi and others 1996a, Paraud and others 2009, Norway Zanzani and others 2014

ML Sheep Denmark, Alvarez-Sánchez and others 2006, Bartley and others 2006, Greece, Italy, Borgsteede and others 1997, Čerňanská and others 2006, Netherlands, Geurden and others 2014, Maingi and others 1996b, MartínezSlovakia, $\quad$ Valladares and others 2013, McMahon and others 2013, Traversa Spain, UK and others 2007

Goats Denmark, Artho and others 2007, Maingi and others 1996a, Murri and Italy, Switzerland others 2014, Zanzani and others 2014

LEV Sheep Denmark, Alvarez-Sánchez and others 2006, Bjørn and others 1991, France, Greece, Borgsteede and others 1997, Chartier and others 1998, Geurden Ireland, Italy, Netherlands, Spain, UK and others 2014, Good and others 2012, Maingi and others 1996b, Martínez-Valladares and others 2013, McMahon and others 2013, Mitchell and others 2010, Taylor and others 2009, Traversa and others 2007

Goats Denmark, Chartier and others 2001, Maingi and others 1996a, Paraud and France others 2009 
MDR Sheep Denmark, Germany, Greece, Ireland, Italy, Netherlands, Spain, UK

Goats Denmark, France
Alvarez-Sánchez and others 2006, Borgsteede and others 1997, Geurden and others 2014, Good and others 2012, Maingi and others 1996b, Martínez-Valladares and others 2013, Mitchell and others 2010, Traversa and others 2007, Voigt and others 2012

Chartier and others 2001, Maingi and others 1996a

\footnotetext{
Haemonchus contortus

BZ Sheep France, Boersema and others 1987, Borgsteede and others 1997, 2007, Germany, Borgsteede and Duyn 1989, Cawthorne and Cheong 1984, Greece, Čerňanská and others 2006, Domke and others 2012a,b, Gallidis Netherlands, Norway, and others 2012, Geurden and others 2014, Grimshaw and others Slovakia, 1994, Hertzberg and others 2000, Höglund and others 2009, Hong Sweden, and others 1992, Jordi 1980, Meyer 2001, Scheuerle and others Switzerland,

UK 2009
}

Goats France, Borgsteede and others 1996, Cabaret and others 1995, Chartier Netherlands, Switzerland

ML Sheep Czech and others 1998, 2001, Hertzberg and others 2000, Meyer 2001, Schnyder and others 2005 Artho and others 2007, Borgsteede and others 1997, 2007, Republic, Čerňanská and others 2006, Geurden and others 2014, Scheuerle Germany, and others 2009, Vadlejch and others 2014, Zanzani and others Greece, Italy, 2014 Netherlands, Slovakia, Switzerland

Goats Germany, Artho and others 2007, Murri and others 2014, Scheuerle and Switzerland others 2009, Schnyder and others 2005

LEV Sheep Greece, Borgsteede and others 1997, Geurden and others 2014 Netherlands

Goats France Chartier and others 2001

MDR Sheep Greece, Borgsteede and others 1997, Geurden and others 2014, Van den Netherlands Brom and others 2013

Goats France, Chartier and others 2001, Schnyder and others 2005 Switzerland

Ostertagia ostertagi 
ML Cattle Germany, Demeler and others 2009

Sweden

\section{Cooperia oncophora}

ML Cattle Belgium, Areskog and others 2013, Bartley and others 2012, Coles and Germany, others 1998, Demeler and others 2009, El-Abdellati and others Ireland, 2010a,b, McArthur and others 2011, O'Shaughnessy and others Sweden, UK 2014, Stafford \& Coles 1999

Other $^{\mathrm{c}}$

BZ Sheep Ireland, Bartley and others 2003, Borgsteede 1986, Burgess and others Netherlands, 2012, Calvete and others 2012, Grimshaw and others 1994, Keane Slovakia, and others 2014, Praslička and others 1994, Várady and others Spain, UK 2006, de Waal, T. and others unpublished observations

LEV Sheep Ireland, UK Burgess and others 2012, Grimshaw and others 1994, Keane and others 2014

ML Sheep Ireland Keane and others 2014

MDR Sheep UK Burgess and others 2012

${ }^{\mathrm{a}} \mathrm{AH}=$ anthelmintic, $\mathrm{BZ}$ = benzimidazoles (including pro-BZs), $\mathrm{ML}=$ macrocyclic lactones, $\mathrm{LEV}=$ levamisole, $\mathrm{MDR}=$ multiple drug resistance

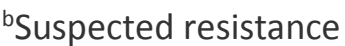

'Other minor species, or species/genera not identified 